\title{
Melanoma do aparelho ungueal ${ }^{*}$ Nail apparatus melanoma*
}

Ignez Regina dos Santos Muri Mendonça ${ }^{1}$

Letícia Pereira Spinelli ${ }^{3}$
Bernard Kawa Kac ${ }^{2}$

Renata Rodrigues Orofino ${ }^{3}$
Renata Teixeira da Silva ${ }^{3}$ Janine Ribeiro França ${ }^{3}$

\begin{abstract}
Resumo: 0 melanoma do aparelho ungueal é apresentação relativamente rara dessa neoplasia, muitas vezes diagnosticada como nevo juncional, hematoma subungueal ou mesmo onicomicose. Esse fato leva a um atraso no diagnóstico e, conseqüentemente, na instituição da terapêutica específica, contribuindo para agravar o prognóstico de uma doença que por si só já é muito agressiva. Os autores relatam um caso de melanoma no primeiro quirodáctilo esquerdo de uma paciente negra com evolução de um ano, ressaltando a importância de avaliar certos critérios clínicos para obter o diagnóstico em fases mais precoces da doença.
\end{abstract}

Palavras-chave: doenças da unha; melanoma; neoplasias.

\begin{abstract}
Nail apparatus melanoma is a rare presentation of melanoma and may be misdiagnosed as junctional nevus, subungual hematoma or onychomycosis. This fact often leads initially to inap propriate treatment and significant delays in appropriately managing such an aggressi ve disease. The authors report a case of melanoma on the left thumb of a black patient evolving for a year. Emphasis was placed on the importance of assessing certain clinical characteristics in order to reach an early diagnosis.

Key words: nail diseases; melanoma; neoplasms.
\end{abstract}

\section{INTRODUÇÃO}

O melanoma do aparelho ungueal (MAU) é apresentação rara dessa neoplasia, sendo considerada uma variante do melanoma lentiginoso acral. Estima-se que sua incidência varie entre $0,7 \%$ e $3,5 \%$ de todos os casos de melanoma. ${ }^{1}$ Freqüentemente diagnosticado nos idosos, entre a quinta e a sétima décadas, sem predomínio entre os sexos. É forma comum em negros e asiáticos, muito embora alguns autores prefiram não associar a epidemiologia do tumor nessa topografia com a raça, tipo de pele ou exposição ao sol. ${ }^{1}$ Dor e desconforto são sintomas pouco freqüentes. Pode determinar deformidade da lâmina ungueal quando tiver origem no leito, porém grande parte surge casualmente, como uma lesão pigmentada no polegar ou no hálux. ${ }^{2}$ Aapresentação clínica mais comum é uma mácula marrom ou negra com pouco tempo de evolução. As formas amelanóticas podem ser confundidas com granuloma piogênico. Onicomicose, hematoma subungueal, melanoníquia estriada e nevo juncional podem simular

\section{INTRODUCTION}

Nail Apparatus Melanoma (NAM) is a rare presentation of this neoplasm. It is considered a variant of acral lentiginous melanoma. Its incidence is estimated to vary from $0.7 \%$ to $3.5 \%$ of all cases of melanoma. ${ }^{1}$ It is frequently diagnosed in aged patients between the fifth and seventh decade of life, and no predilection for sex has been noticed. It is common among black and Asian persons. Nonetheless, many authors prefer not to associate the epidemiology of the tumor in this topography with race, skin type or sun exposure. Pain and discomfort sel dom occur as symptoms. A deformation of the ungual blade may be noticed when originating in the nail bed. However, most cases arise gradually in the form of a pigmented lesion on the thumb or the hallux (great toe). ${ }^{2}$ The most common clinical pre sentation is a brown or black macule of short duration. Amelanotic forms might be mistaken for pyogenic granuloma. Onychomycosis, subungual hematoma, striated melanonychia and junctional nevus might simulate NAM and must be included

\footnotetext{
Recebido em 05.12.2001. / Received on December 05, 2001.

Aprovado pelo Conselho Consultivo e aceito para publicação em 10.09.2003. / Approved by the Consultive Council and accepted for publication on September 10, 2003.

* Trabalho realizado no Instituto de Dermatologia R D Azulay; Centro de Estudo da Unha - Céu; Santa Casa da Misericórdia do Rio de Janeiro. / Work done at R D Azulay Dermatology

Institute; "Centro de Estudo da Unha-Ceu" (Nail Study Center); "Santa Casa da Misericórdia do Rio de Janeiro", Rio de Janeiro State.

' Especialista em Dermatologia. Chefe do Centro de Estudo da Unha do Instituto de Dermatologia da Santa Casa- RJ./ Dermatology specialist. Head of the Santa Casa Dermatology Institute nail Study Center, Rio de Janeiro state.

${ }^{2}$ Chefe do Setor de Histopatologia do Instituto de Dermatologia da Santa Casa- RJ. / Head of the histopathology sector of the Santa Casa Dermatology institute, Rio de Janeiro state.

${ }^{3}$ Alunos do Curso de Pós-Graduação em Dermatologia. / Students of the Postgraduate program in Dermatology.
} 
o MAU e devem entrar no diagnóstico diferencial. ${ }^{3} \mathrm{O}$ derrame de pigmento melânico nas bordas proximal e lateral da lâmina (sinal de Hutchinson) é indicativo de doença avançada. ${ }^{1,13}$ Além do diagnóstico clínico, muitas vezes auxiliado pela dermatoscopia, a análise histopatológica é de fundamental importância para o diagnóstico. $\mathrm{O}$ tratamento depende do estadiamento e tem a cirurgia como grande opção. O prognóstico é reservado devido a seu comportamento agressivo e, sobretudo, pelo diagnóstico tardio na maioria dos casos. ${ }^{4}$

\section{RELATO DO CASO}

Paciente do sexo feminino, 65 anos, negra, que, um ano após traumatismo no polegar esquerdo, notou lesão enegrecida próximo da cutícula estendendo-se pela lâmina ungueal, assintomática. Não apresentava alterações prévias na unha. $\mathrm{O}$ exame do dígito demonstrava evidente melanoníquia ocupando quase toda a superfície da lâmina ungueal, onicólise distal, distrofia mediana com fratura distal da lâmina ungueal, além de pigmentação periungueal (Figuras 1, 2 e 3). Apresentava linfoadenomegalia axilar esquerda, móvel, indolor, com cerca de $1,5 \mathrm{~cm}$. O diagnóstico clínico foi melanoma, e a paciente, submetida à biópsia incisional. A histopatologia evidenciou melanócitos atípicos infiltrando a derme reticular, com núcleos ovalados, hipercromáticos e acentuada pigmentação melânica citoplasmática (Figuras 4 e 5 ) além da infiltração da lâmina e da epiderme circunjacente. Foi feita a amputação da falange distal e retirada dos gânglios axilares no serviço de oncologia que se responsabilizou pelo acompanhamento do caso.

\section{DISCUSSÃO}

O MAU foi primeiramente descrito por Boyer, em $1834,{ }^{5}$ e, na língua inglesa, por Hutchinson, em $1886 .{ }^{6}$

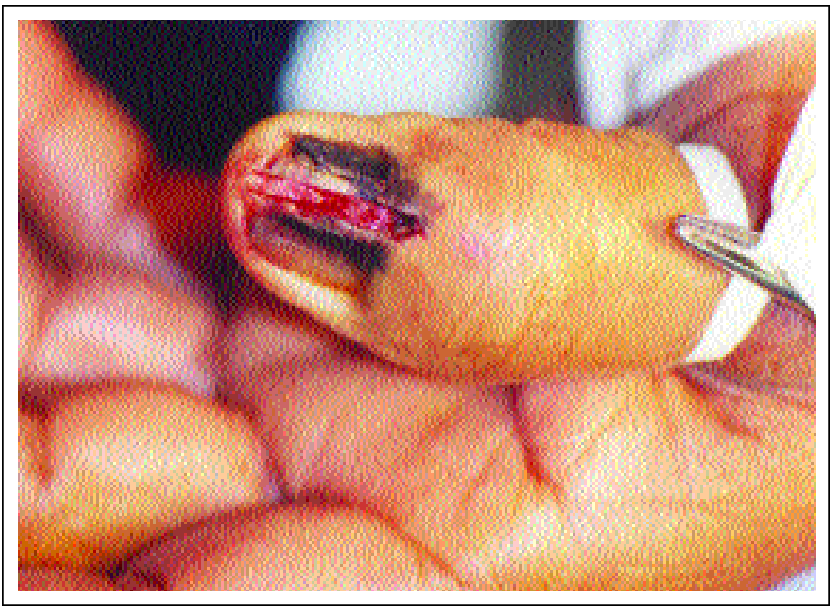

Figura 1: Lesão melanocítica envolvendo matriz, lâmina, leito e dobra ungueal proximal (Sinal de Hutchinson).

Figure 1: Melanocytic lesion with involvement of the nail matrix, plate, bed and proximal nail fold (Hutchinson`s sign). in the differential diagnosis. ${ }^{3}$ The spread of the melanoma pig ment into the proximal and lateral edges of the blade (Hutchinson's sign) is indicative of the advanced stage of the disease. ${ }^{1,13}$ In addition to the clinical diagnosis, which is often assisted by dermatoscopy, the histopathological analysis is of capital importance for the diagnosis. Treatment depends on sta ging, and surgery is a frequent option. The prognosis is subject to a reservation owing to the disease's aggressive behavior and, above all, a delayed diagnosis in most cases. ${ }^{4}$

\section{CASE REPORT}

The report discusses the case of a 65-year-old black female patient. A year after experiencing trauma on the left thumb, the patient noticed a dark lesion close to the cuticle extending to the ungual, asymptomatic blade. The patient had no previous alterations on the fingernail. The examination of the finger demonstrated a clear case of melanonychia vir tually occupying the entire surface of the ungual blade, distal onycholysis, and median nail dystrophy with a distal fracture of the ungual blade, in addition to periungual pigmentation (Figures 1, 2 and 3). The patient presented with left axillary lymphadenomegaly that was mobile and painless, roughly measuring $1.5 \mathrm{~cm}$. The clinical diagnosis was melanoma. The patient was referred for an incisional biopsy. Histopathology exposed atypical melanocytes infiltrating the reticular dermis, with oval hyperchromatic nuclei, and accentuated cytoplas mic melanin pigmentation (Figures 4 and 5) in addition to an infiltration of the blade itself and the surrounding epidermis. The distal phalanx was amputated and the axillary ganglions removed. It was carried out at the oncology service, which also took charge of following up the case.

\section{DISCUSSION}

NAM was first described by Boyer in $1834,{ }^{5}$ and in English by Hutchinson in $1886 .^{6}$

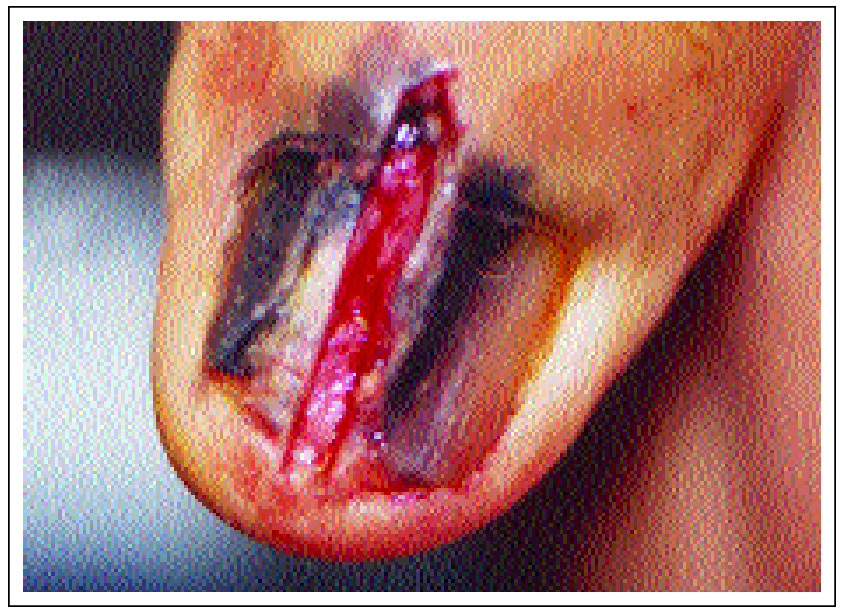

Figura 2: Biópsia incisional Figure 2: Incisional biopsy. 
Figura 3: Perfil da lesão.

Estima-se que variações de 2 a $3 \%$ dos melanomas em brancos e de 15 a 20 $\%$ em negros estejam localizadas no aparelho ungueal. Entretanto, não há diferença significativa do número de casos de melanoma ungueal entre indivíduos brancos e negros. ${ }^{7}$ A incidência em crianças é rara, apesar do aumento do número de casos de melanoma. ${ }^{8}$

Deve ser suspeitado toda vez que surgir mácula hipercrômica (marrom ou negra) na matriz, leito ou lâmina ungueal. Também sugere melanoma uma faixa longitudinal enegrecida com pouco tempo de evolução em caucasianos ou a mudança clínica de uma lesão preexistente. O derrame de pigmento melânico é sempre sugestivo do tumor. A literatura faz referência ao fato de, casualmente, o indivíduo perceber uma lesão melanocítica antes ausente, e apenas dois terços dos pacientes procurarem o médico em função do surgimento da lesão. ${ }^{7}$ A biópsia está indicada em toda melanoníquia longitudinal adquirida após a puberdade em indivíduos de pele clara ou na presença de melanoníquia longitudinal que apresente crescimento rápido e progressivo. ${ }^{7,9}$

Os nevos melanocíticos congênitos ou adquiridos podem ter origem na matriz e apresentar-se clinicamente como uma melanoníquia longitudinal. São raros e, geralmente, do tipo juncional. Aarquitetura histopatológica é semelhante à de um nevo de localização na pele. Células névicas simples podem ser encontradas na camada basal e suprabasal dos oni-
Figure 3:

Lesion profile.

It is estimated that there is a $2-3 \%$ variation in melano mas localized on the nail appa ratus in whites and 15-20\% in black persons. Nevertheless, there is no significant differen ce in the number of cases of nail melanoma between white and black persons. ${ }^{7}$ Incidence in children is rare despite the increase in the overall number of melanoma cases. ${ }^{8}$

This disease must be suspected anytime a (brown or black) hyperchromic macule appears on the nail matrix, bed or blade. Also suggestive of melanoma is a black longi tudinal streak of short duration in white persons, and a cli nical change of a preexisting lesion. The spread of the mela nin pigment is always suggestive of a tumor. The literature refers to how individuals casually perceive the appearance of a previously inexistent melanocytic lesion, with only twothirds of patients seeking medical care as a result. ${ }^{7}$ A biopsy is recommended for every longitudinal melanonychia acquired after puberty in fair-skinned individuals or in the presence of longitudinal melanonychia showing rapid and progressive growth., ${ }^{7,9}$

Congenital or acquired melanocytic nevi may stem from the nail matrix and clinically present as a longitudinal melanonychia. They are rare and usually of the junctional type. The histopathologic architecture is similar to a nevus localized on the skin. Simple nevic cells may be found in the basal and supra basal layers of the onychocytes. Dendritic

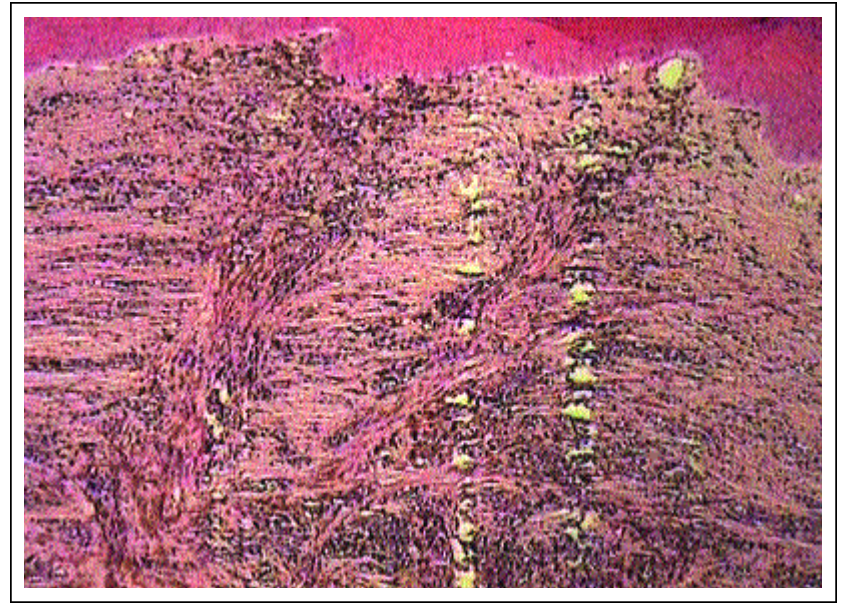

Figura 4: A histopatologia evidenciou melanócitos atípicos infiltrando a derme reticular. / Figure 4: Histopathology showed atypical melanocytes infiltrating the reticular dermis.

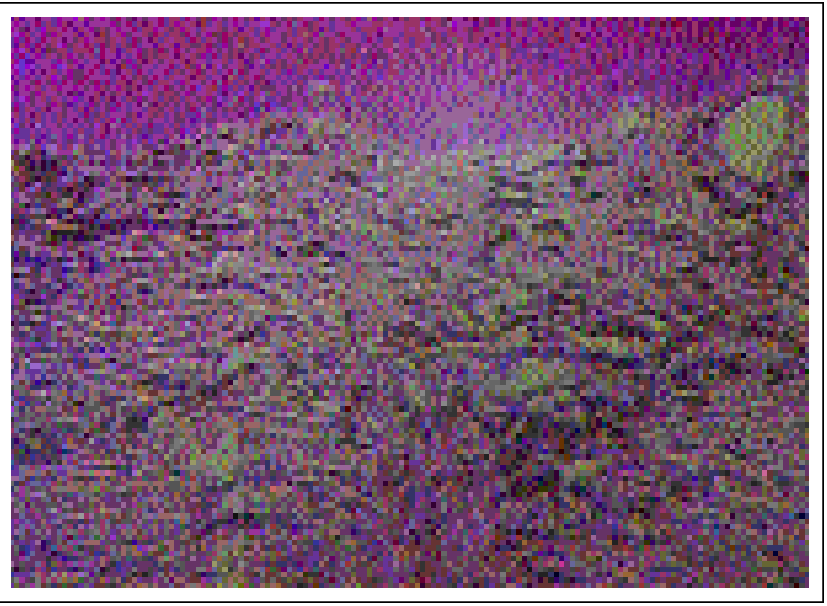

Figura 5: Melanócitos atípicos constituídos por núcleos ovalados e hipercromáticos, e acentuada pigmentação melânica citoplasmática / Figure 5: Atypical melanocytes constituted of oval and hyperchro matic nuclei, and accentuated cytoplasmatic melanin pigment . 
cócitos. Melanócitos dendríticos só estão presentes ocasionalmente na matriz ungueal. Ahiperplasia melanocítica benigna, que se caracteriza pelo aumento do número de melanócitos entre os queratinócitos da matriz sem formarem ninhos, deverá ser igualmente distinguida do nevo e do MAU, o que é por vezes difícil. As melanoníquias longitudinais suspeitas deverão ser completamente excisadas e analisadas do ponto de vista histopatológico e imuno-histoquímico. A freqüência da progressão de um nevo para melanoma do aparelho ungueal não é conhecida, e a literatura informa que podem desaparecer espontaneamente. ${ }^{7}$ A dermatoscopia poderá auxiliar no diagnóstico diferencial das lesões melanocíticas. ${ }^{10}$

Ocasionalmente, um hematoma subungueal pode exigir diagnóstico diferencial com melanoma. A cor azul-avermelhada, a irregularidade da lesão e a ausência do pigmento na lâmina sugerem hematoma. Além disso, o sangue armazenado entre a lâmina e o leito ungueal é deslocado para frente com o crescimento do fânero. Além disso, a hemoglobina subungueal não é degradada em hemossiderina pelo macrófago. A coloração pelo azul da Prússia favorece o diagnóstico de hematoma. A diferença entre a hemossiderina e o pigmento melânico na histopatologia, porém, algumas vezes exige análise ultra-estrutural: o ferro é intercelular, e a melanina, intracelular. ${ }^{7} \mathrm{Na}$ dermatoscopia a formação de pseudópodes é em geral resultado da penetração de eritrócitos nas camadas da lâmina ungueal e pode servir de critério para distinguir um hematoma de um melanoma

Agentes como Candida guilliermondii, Tricho phyton rubrum nigricans, Scytalidium sp, Trichosporum beigelli, entre outros, podem determinar melanoníquia. A suspeita clínica de micose, associada aos exames micológicos positivos e a histopatologia são definitivas para esclarecer o diagnóstico.

Ao contrário do melanoma cutâneo em que $80 \%$ dos casos são TNM I, ${ }^{11}$ apenas $20 \%$ dos casos de MAU estão no estágio I do TNM (classificação para tumor primário, linfonodos regionais e metástases) no momento do diagnóstico. Visando reverter esta situação, Levit $e$ col. ${ }^{11}$ idealizaram um sistema de fáceis memorização e aplicação. Algumas características foram agrupadas segundo as letras do alfabeto e designadas como o ABCDEF do MAU:

$\mathrm{A}($ age $)$ - Pico de incidência entre a quinta e a sétima décadas de vida;

B (nail band) - Examinar a faixa: cor geralmente marrom (brown) ou preta (black), espessura (breadth) e bordas (border). A presença de variação de cores, espessura maior do que $3 \mathrm{~mm}$ ou borda irregular devem aumentar a suspeição de melanoma;

C (change) - Rápido ou recente aumento no tamanho da faixa, compatível com a fase de crescimento radial, ou mudança na morfologia da unha sugerem malignidade;

$\mathrm{D}$ (digit involved) - Estima-se, em ordem de frequiência, que seja mais comum no polegar, seguido pelo hálux e a seguir pelo indicador, e na mão dominante. Uma faixa pigmentada em um dígito é mais indicativa de tumor do que melanocytes are only present occasionally on the ungual matrix. Benign melanocytic hyperplasia, which is characte rized by an increase in the number of melanocytes among the keratinocytes of the matrix without forming nests, will have to be equally distinguished from nevus and NAM, which is at times difficult. Suspected cases of longitudinal melanonychia must be completely excised and analyzed from a histopathologic and immunohistochemical point of view. The frequency of a nevus-to-melanoma progression of the nail apparatus is not known. The literature informs us that it may disappear spontaneously. ${ }^{7}$ Dermatoscopy might assist the differential diagnosis of the melanocytic lesions. ${ }^{10}$

Occasionally, a subungual hematoma might require a differential diagnosis with melanoma. The bluish-red color, lesion irregularity and absence of pigment on the blade point to hematoma. Moreover, the blood stored bet ween the ungual blade and bed is displaced toward the front as the appendage grows. In addition, subungual hemoglo bin is not degraded in hemosiderin by the macrophage. Staining with Prussia blue favors a diagnosis of hematoma. However, the difference between hemosiderin and melanin pigment in histopathology sometimes requires an ultrastructural analysis: iron is intercellular whereas melanin is intracellular. In dermatoscopy the formation of pseudopods is usually the outcome of erythrocytes penetrating into the layers of the ungual blade. They can act as criteria to dis tinguish a hematoma from melanoma.

Agents such as Candida guilliermondii, Trichophyton rubrum nigricans, Scytalidium sp, Trichosporum beigelli, among others, might cause mela nonychia. The clinical suspicion of mycosis, in association with the positive mycological examinations and histopatho logy, are decisive for clarifying the diagnosis.

Unlike cutaneous melanoma in which $80 \%$ of cases are MNT-1," only $20 \%$ of NAM cases are at stage I of MNT (a classification for the primary tumor, regional lymphno des and metastases) at the moment of diagnosis. In an attempt to reverse this situation, Levit and col. ${ }^{\text {II }}$ idealized an easy-to-memorize application system. A few characteristics were grouped together according to the letters of the alpha bet and designated as the ABC of NAM:

A (age) - Incidence peak between the fifth and seventh decade of life:

$B$ (nail band) - Examine the streak: color usually brown or black, breath and border. The presence of color variations, breath greater than $3 \mathrm{~mm}$, or an irregular bor der should increase the suspicion of melanoma;

$C$ (change) - Speed and recent increase in size of the streak, compatible with the phase of radial growth, or chan ge in morphology of the nail suggest malignity;

$D$ (digit involved) - The most common sites to be affected, in order of frequency, are assumed to be the thumb, then the hallux and index, and the dominant hand. A pigmented streak on one digit is more indicative of a tumor than its presence on several digits. This is especially 
sua presença em vários dígitos. Isso é especialmente importante, visto que a melanoníquia estriada pode ser encontrada em quase todos os africanos com mais de 50 anos de idade como uma expressão étnica;

E (extension) - É o próprio sinal de Hutchinson, ${ }^{13}$ que consiste na extensão do pigmento na região periungueal;

F (family) - História familiar e pessoal para síndrome do nevo displástico e melanomas prévios.

Apesar de cada letra ter sua importância, o somatório delas implica a possibilidade de diagnóstico mais preciso. Das seis letras do alfabeto para diagnóstico clínico do melanoma, cinco estavam presentes no caso relatado.

O diagnóstico presuntivo de melanoma subungueal na presença do sinal de Hutchinson ${ }^{11,12,13}$ é regra, porém, Baran e col. ${ }^{12}$ enfocam três exceções: doenças benignas, tumores não melanomas e condição ilusória (pseudo sinal de Hutchinson). Dessa feita, poderá estar presente nas síndromes de PeutzJeghers, Laugier-Hunziquer, hematoma subungueal, pigmentação étnica, SIDA, uso de drogas (minociclina e zidovudina), assim como na doença de Bowen.

O exame histopatológico continua sendo o padrão ouro para a confirmação do melanoma. As lesões in situ podem simular um padrão benigno, especialmente na periferia, com aumento nos melanócitos basais e hiperpigmentação com atipia apenas focal dos melanócitos. Entretanto, no centro da lesão, atipia citológica intensa e uniforme é encontrada. A pigmentação é pronunciada, resultando da presença de melanófagos na derme superior e de grandes agregados de melanina na camada córnea. Há possibilidade de infiltrado linfocítico liquenóide que pode obscurecer a junção dermoepidérmica. Esses achados histopatológicos estavam presentes no caso descrito. A biópsia poderá ser incisional ou excisional.

Com base nos critérios clínicos e histopatológicos o prognóstico do MAU é pior do que o do melanoma cutâneo, com taxas de sobrevida em cinco anos variando entre $16 \%$ e $87 \%$, sendo que mais de $50 \%$ dos pacientes morrem antes de completar cinco anos. ${ }^{11}$

O tratamento tradicional tem sido a amputação do dígito acometido, na altura da articulação proximal, desde que as margens estejam livres de doença. Alguns estudos têm avaliado a eficácia da cirurgia micrográfica de Mohs para o tratamento do melanoma in situ, com a vantagem de preservar os tecidos nobres para a função adequada do segmento afetado. ${ }^{13}$

A detecção das lesões iniciais do MAU é fundamental não só para aumento na sobrevida, mas também para a preservação da falange. É preciso estar alerta para a identificação correta das alterações ungueais sugestivas de melanoma, além de para os dados epidemiológicos associados à doença. important, given that striated melanonychia may be found in virtually all Africans over 50 years in age as an ethnic feature;

E (extension) - This is the Hutchinson's sign itself, ${ }^{13}$ which consists of the pigment extending to the periungual region;

F (family) - Family and personal background for dysplastic nevus syndrome and previous melanomas.

Even though each letter has its own importance, the sum of them leads to the possibility of a more accurate diag nosis. Of the six letters of the alphabet utilized for the clini cal diagnosis of melanoma, five were present in the case reported.

A presumed diagnosis of subungual melanoma when the Hutchinson's sign is present has proved to be the rule. ${ }^{1,12,13}$ However, Baran et al. ${ }^{12}$ focused on three excep tions: benign diseases, nonmelanomous tumors and the illu sory condition (pseudo Hutchinson's sign). Accordingly, it might be present in Peutz-Jeghers and Laugier-Hunziquer syndromes, subungual hematoma, ethnic pigmentation, AIDS, drug use (minocycline and zidovudine), as well as Bowen's disease.

A histopathologic examination continues to be the golden standard for confirming melanoma. The lesions in situ may simulate a benign pattern, especially along the contour, with an increase in basal melanocytes and hyper pigmentation with only focal atypia of the melanocytes. Nevertheless, in the middle of the lesion, intense and uni form cytologic atypia is found. Pigmentation is pronounced, resulting in the presence of melanophages in the upper dermis and large melanin aggregates in the corneal layer. Also, lichenoid lymphocytic infiltrate could plausibly blur the dermoepidermal junction. These histopathologic findings were present in the case described. The biopsy can be either incisional or excisional.

Based on the clinical and histopathologic criteria, the prognosis of NAM is worse than cutaneous melanoma, with survival rates over five years varying from $16 \%$ to $87 \%$. More than $50 \%$ of patients die prior to completing the five years. ${ }^{\prime \prime}$ The traditional treatment has been amputation of the affected digit, at the height of the proximal joint, once the margins are freed of the disease. Some studies have assessed the effectiveness of Mohs micrographic surgery for treating the melanoma in situ. Its advantage is to preserve noble tis sue for the affected segment to function adequately. ${ }^{13}$

Detecting the first NAM lesions is fundamental not only for improving the patient's chances of survival, but also for preserving the digit. The physician must be alert and correctly identify any nail alterations that might be suggestive of mela noma, in addition to being aware of the epidemiological data associated with the disease. 


\section{REFERÊNCIAS / REFERENCES}

1. Langley RG, Barnhill RL, Fitzpatrick TB. Fitzpatrick's Dermatology in general medicine. 5nd ed vol I. New York: Mc Graw Hill; 1999. p. 1080-116.

2. O'Toole E, Stephens R, Young M, Tanner A, Barnes L. Subungual Melanoma: a relation to direct injury? J Am Acad Dermatol. 1995; 33:525-8.

3. Glat PM, Spector JA, Roses DF. The management of pigmented lesions of the nail bed. Ann Plast Surg. 1996; 37: 25-34.

4. Paul E, Kleiner H, Bodeker RH. Epidemiology and prognosis of subungual melanoma. Hautarzt. 1992; 43: 286-90

5. Boyer A. Fungus Hematide du petit digit. Ganz Med Paris. 1834: 212.

6. Hutchinson J. Melanosis often not black: melanotic whitlow. Br Med J. 1886; 1: 491.

7. Baran R, Dawber RPR. Diseases of the nail and their management. 2nd ed. Oxford: Blackwell Science;1994. p. 483-497.

8. Goettman-Bonvallot S, Andre J, Belaich S. Longitudinal melanonychia in children: a clinical and histopathologic study of 40 cases. J Am Acad Dermatol. 1999; 41:17-22. 9. Tosti A, Baran R, Piraccini BM, Cameli N, Fanti PA. Nail matrix nevi: a clinical and histophatologic study of twenty- two patients. J Am Acad Dermatol. 1996; 34:765-71.

10. KawabataY, Ohara K, Hino H, Tamaki K. Two kinds of Hutchinson's sign, benign and malignant. J Am Acad Dermatol. 2001; 44:305-7.

11. Levit EK, Kagen MH, Scher RK, Grossman M, Altman E. The $A B C$ rule for clinical detection of subungual melanoma. J Am Acad Dermatol. 2000; 42:269-74.

12. Baran R, Kechijian P. Hutchinson's sign: a reappraisal. J Am Acad Dermatol. 1996; 34:87-90.

13. Banfield CC, Dawber RP, Walker NP, Stables GI, Zeina B, Schomberg K. Mohs Micrographic surgery for the treatment of in situ nail apparatus melanoma: a case report. J Am Acad Dermatol. 1999; 40:98-9.

EndereÇO PARA CORRESPONDÊNCIA: / MAILING AdDRESS: Ignez Regina dos Santos Muri Mendonça Rua Dona Mariana, 136/ 204 - Botafogo 22280-020 Rio de Janeiro RJ

Tel./Fax: (21) 2538-0049

E-mail: ignezmendonca@superig.com.br 